\title{
Perbedaan Mobilisasi Dini 6 Jam dan 8 Jam Terhadap Peristaltik Usus Pada Pasien Post Operasi Dengan anastesi Umum di RS. dr. R. Soeprapto Cepu
}

\author{
Purnomo Heru ${ }^{1 *}$ Mu'awanah ${ }^{2}$ Mudhofar Muhammad Nor ${ }^{3}$ \\ 1,2,3 Prodi D-III Keperawatan Blora, Poltekkes Kemenkes Semarang, Indonesia
}

\section{*Corresponding author : Heru Purnomo}

Email: purnomoheru@ymail.com

Received: March 11, 2020; Accepted: March 20, 2020, Published : March 31, 2020

\begin{abstract}
Background : Early mobilization is some effort to defend autonomy as early as possible by guiding the victim for defending fisiologis function (Carpenito, 2001). According Smeltzer \& Bare (2002) in patient with colon inflammation disturbance, explained that change position encourage doing passive and active exercise to depend muscle and prevent tromboembolic. Activity limitation changed suitable with daily necessary. General anesthesia can cause decreasing colon movement with stimuli parasympatic obstruction in colon muscle. Client with local anesthesia will experience same case. Direction surgery which involved intestinal can cause stopping intestinal while movement. Surgery action with general anesthesia in RS.DR.R.Soeprapto Cepuoften was being done in juny - December 2012 period reported 166 cases.

Objective : This study to determine the difference of early mobilization 6 hours and 8 hours toward intestine peristaltic on post operation patient with general anesthesia at RSUD dr. R. Soeprapto Cepu.

Methods : Method of this research used quasi eksperimental design and taking sampling method was stratified random sampling, research was done into 20 respondences. Collecting data technique using observation technique. Statistic analysis used Independent t-test exam, organize and data analysis with computer program assist SPSS for windows 16.

Result : The result analysis was shown with independent $t$-test exam was be found $t$ hitung $0,662, t$ table $2,101, p$ value 0,641 . Where is thitung $<t$ table $(0,662<2,101)$ and $p$ value $>$ alpha $(0,641>0,05)$ above can be conclude Ho was accepted. Its mean its'nt difference early mobilization 6 hours and 8 hours about peristaltic of intestine for post operation patient with general anesthesia in dr.R.Soeprapto Cepu Hospitals.

Conclusion : Advice we recommend early mobilization of patients immediately after surgery with general anesthesia, according to the results of this study was able to mobilize patients early in the post anesthesia 6 hours.
\end{abstract}

Keywords: mobilisation, peristaltic of intestine, post operation, general anesthesia.

\section{Pendahuluan}

Klien yang mendapat anastesi umum akan memberi dampak perubahan fisiologis tubuh, yang cenderung menghadapi komplikasi yang lebih besar dari pada yang hanya mendapat anastesi local. Perubahan fisiologis akibat anastesi umum antara lain pada fungsi pernapasan, sirkulasi, neurologis, genitourinaria, gastrointestinal (Potter \& Perry, 2009). Pada klien yang dilakukan tindakan pembedahan dengan anastesi umum, mobilisasi sudah dapat dilakukan 8 jam pasca anastesi, tentu setelah pasien sadar atau anggota gerak tubuh dapat digerakkan kembali setelah dilakukan pembiusan. Manfaat dari mobilisasi dini antara lain mendapatkan kembali fungsi fisiologi normal. Salah satunya adalah faal usus dan kandung kencing lebih baik dan akan merangsang peristaltic usus kembali normal (Carpenito, 2001). Penelitian yang dilakukan oleh Narko \& Arifah (2008) mengatakan bahwa pasien setelah 8 jam pasca anastesi melakukan mobilisasi dengan dibantu perawat ternyata akan mempercepat terjadinya flatus, melancarkan peredaran darah dan menghindari komplikasi lainnya. Kompetensi perawat yang dapat dilakukan pada pasien post operasi diantaranya membantu 
melakukan mobilisasi dini yaitu upaya mempertahankan kemandirian sedini mungkin dengan cara perawat membimbing klien untuk mempertahankan fungsi fisiologisnya ( Carpenito, 2001 ). Pasien atau keluarga pasien sering kali mempunyai pandangan yang keliru tentang pergerakan pasien setelah operasi. Banyak pasien yang tidak berani menggerakkan tubuh karena takut jahitan operasi akan sobek atau takut luka operasi akan lama sembuh. Pandangan itu jelas keliru karena justru jika pasien selesai operasi dan segera bergerak maka pasien akan lebih cepat kentut atau flatus (Asrob, 2009).

\section{Metode Penelitian}

Penelitian ini menggunakan desain quasi eksperimental dengan pendekatan post test design only dengan control group dan metode pengambilan sampel adalah stratified random sampling, penelitian dilakukan pada 20 responden. Tehnik pengumpulan data menggunakan tehnik observasi, Analisis staristik menggunakan uji Independent $t$-test, pengolahan dan analisis data dengan bantuan computer menggunakan SPSS for windows 16.

\section{Hasil dan Pembahasan}

A. Karakteristik Responden

Tabel 1. Distribusi frekuensi karakteristik responden berdasarkan umur, jenis kelamin, pendidikan, diagnosa medis

\begin{tabular}{lcccc}
\hline \multirow{2}{*}{ Karakteristik } & \multicolumn{2}{c}{$\mathbf{6}$ jam } & \multicolumn{2}{c}{$\mathbf{8}$ jam } \\
\cline { 2 - 5 } & $\mathbf{f}$ & $\mathbf{\%}$ & $\mathbf{f}$ & $\mathbf{\%}$ \\
\hline Umur & & & & \\
$30-40$ & - & - & 2 & 20 \\
$41-50$ & 5 & 50 & 4 & 40 \\
$51-60$ & 2 & 20 & 2 & 20 \\
$61-70$ & 3 & 30 & 2 & 20 \\
Jenis kelamin & & & & \\
Laki-Laki & 8 & 80 & 7 & 70 \\
Perempuan & 2 & 20 & 3 & 30 \\
Pendidikan & & & & \\
Tdk Sekolah & 3 & 30 & 3 & 30 \\
SD & 6 & 60 & 4 & 40 \\
SMP & 1 & 10 & 2 & 20 \\
SMA & - & & 1 & 10 \\
Diagnosa Medis & & & & \\
Hernia & 5 & 50 & 4 & 40 \\
Lipoma & 1 & 10 & - & - \\
BPH & 1 & 10 & 1 & 10 \\
Myoma & 1 & 10 & 3 & 30 \\
Kistoma & 1 & 10 & - & - \\
APP & 1 & 10 & 2 & 20 \\
\hline
\end{tabular}

Dari table 1 terlihat bahwa dari karakteristik usia di kelompok perlakuan 6 jam prosentase terbesar pada usia 41-50 tahun yaitu sejumlah 5 responden (50\%) dan di kelompok perlakuan 8 jam prosentase terbesar juga pada usia 41-50 tahun yaitu 4 responden (40\%). Penelitian ini sebagian besar adalah berusia dewasa, sehingga dalam pelaksanaan latihan berpengaruh terhadap terhadap latihan yang diberikan oleh perawat. Smeltzer \& Bare (2002) juga menjelaskan bahwa umur semakin tua mempunyai cadangan fisiologis (kemampuan dari suatu organ untuk kembali normal setelah mengalami gangguan dalam equilibriumnya) lebih rendah dibanding pasien yang lebih muda. Pada lansia cadangan protein plasmanya lebih rendah, dengan menurunnya protein plasma lebih banyak agens anastesi yang bebas dan tidak berikatan sehingga menyebabkan kerja anastesi lebih kuat yang menyebabkan pada lansia lebih lama sadarnya setelah anastesi umum (Smeltzer \& Bare, 2002).

Karakteristik jenis kelamin prosentase terbesar baik di kelompok 6 jam maupun 8 jam adalah laki-laki sebanyak 8 responden $(80 \%)$ dikelompok 6 jam dan 7 responden (70\%) dikelompok 8 jam. Laki-laki cenderung mampu secara fisiologis dalam melakukan kegiatan fisik sehingga mekanisme kekuatan tubuh dapat menyesuaikan pada kondisi pemulihan (Siregar, 2004). Pada laki-laki cenderung lebih cepat sadar setelah pemberian anastesi umum dapat juga dikarenakan pengaruh dari kehidupan sehari-hari, karena laki-laki cenderung mempunyai kebiasaan alkoholik yang bisa mempengaruhi efek dari fungsi anastesi umum (Kompas.com, 2009).

Berdasarkan karakteristik diagnose medis prosentase terbesar pada diagnose medis hernia yaitu sebanyak 5 responden $(50 \%)$ pada kelompok 6 jam dan 4 responden (40\%) dikelompok 8 jam. Peneliti belum menemukan mekanisme fisiologis hernia lebih banyak, peneliti menyimpulkan diagnose Hernia cenderung lebih banyak karena ini merupakan hal yang kasuistik di RS. dr. R. Soeprapto Cepu.

B. Waktu Munculnya Peristaltik

Tabel 2. Distribusi frekuensi berdasarkan waktu munculnya peristaltic usus pada mobilisasi 6 jam dan mobilisasi 8 jam

\begin{tabular}{ccccc}
\hline \hline Waktu & \multicolumn{2}{c}{ 6 jam } & \multicolumn{2}{c}{ 8 jam } \\
\cline { 2 - 5 } Peristaltic & f & \% & f & \% \\
\hline \hline $10^{\prime}$ & 1 & 10 & 2 & 20 \\
$15^{\prime}$ & 4 & 40 & 3 & 30 \\
$20^{\prime}$ & 2 & 20 & 4 & 40 \\
25 & 3 & 30 & 1 & 10 \\
\hline \hline Jumlah & 10 & 100 & 10 & 100 \\
\hline
\end{tabular}


Berdasarkan table 2 prosentase terbesar berdasarkan waktu munculnya peristaltic dikelompok 6 jam yaitu pada 15' sebanyak 4 responden (40\%) dan dikelompok 8 jam juga pada 20' yaitu sebanyak 4 responden (40\%). Di kelompok 6 jam peristaltic yang muncul di 10' pertama sebanyak 1 responden (10\%) dan dikelompok 8 jam peristaltic yang muncul di 10' pertama sebanyak 2 responden (20\%). Dengan adanya aktifitas pada tubuh setelah pemberian anastesi umum akan mempengaruhi sekresi kelenjar usus yang dapat merangsang keluarnya hormon neuroregulator dan regulator local yang berfungsi untuk mengontrol laju sekresi usus dan akan mempengaruhi motilitas gastrointestinal sehingga mampu meningkatkan gerakan usus. Susan J.Garrison (2007) manfaat dari mobilisasi dini diantaranya untuk memperlancar peredaran darah, sehingga faal usus dan kandung kencing akan menjadi lebih baik. Dengan bergerak akan merangsang peristaltic usus kembali normal.

C. Analisa Perbedaan Waktu Mobilisasi Dini

Uji normalitas data menggunakan hasil uji Shapiro wilk karena data kurang dari 50 responden (Sopiyudin, 2004). Pada uji ini diperoleh nilai sig $(\infty)$ untuk peristaltic pada mobilisasi 6 jam $0,111>0,05$ maka data berdistribusi normal. Dan nilai sig $(\infty)$ untuk peristaltic pada mobilisasi 8 jam $0,245>0,05$ maka data berdistribusi normal.

Table 4 Uji Independent t Test

\begin{tabular}{lccc}
\hline & $\mathrm{F}$ & $p$ value & $\mathrm{t}$ \\
\hline $\begin{array}{l}\text { Equal variances } \\
\text { assumed }\end{array}$ & .225 & .641 & .662 \\
$\begin{array}{l}\text { Equal variances } \\
\text { not assumed }\end{array}$ & & & \\
\hline
\end{tabular}

Pada uji varian ini diperoleh nilai $\mathrm{p}$ value $0,641>0,05$ artinya kedua varian sama dengan penggunaan uji t menggunakan Equal variances assumed pada uji Independent $t$ - test diperoleh nilai $\mathrm{t}$ hitung 0,662 nilai $\mathrm{t}$ table sebesar 2,101. Oleh karena nilai $\mathrm{t}$ hitung $<\mathrm{t}$ table $(0,662<$ $2,101)$ dan $p$ value $>0,05(0,641>0,05)$ Maka diperoleh kesimpulan bahwa Ho diterima yang artinya tidak ada perbedaan antara mobilisasi 6 jam dan 8 jam terhadap peristaltic usus pada pasien post operasi dengan general anastesi. Mobilisasi ternyata juga sudah bisa dilakukan 6 jam pasca anastesi umum dimana peristaltic pun sudah muncul, jadi pasien sudah bisa mengakhiri puasanya lebih awal. Meskipun dari hasil penelitian didapatkan tidak ada perbedaan antara mobilisasi 6 jam dan mobilisasi 8 jam pada pasien post operasi dengan general anastesi akan tetapi hasil dari penelitian ini tidak bisa digeneralkan dari segi kasus atau jenis penyakit pasien (tidak bisa menjadi patokan di RS lain), karena banyak factor yang mempengaruhi yaitu dengan kasus yang beragam tidak satu jenis kasus. Jadi hasil penelitian ini hanya bersifat untuk kasus di RS Cepu dan pada waktu peneliti melakukan penelitian.

\section{Kesimpulan}

Dari hasil penelitian setelah dilakukan mobilisasi 6 jam pasca anastesi umum peristaltic sudah muncul dalam waktu 10' menit post mobilisasi dan tidak terdapat perbedaan antara mobilisasi 6 jam dan 8 jam pasca anastesi pada pasien post operasi dengan general anastesi di RS dr. R. Soeprapto Cepu.

Rumah sakit sebaiknya menetapkan prosedur tetap bagi pasien pasca operasi dengan general anastesi agar segera dilakukan mobilisasi dini pada 6 jam paska anastesi untuk mempercepat proses pemulihan peristaltic usus..

\section{Acknowledgement}

Ucapan banyak terimakasih disampaikan kepada semua pihak yang telah membantu terlaksananya kegiatan penelitian oleh tim Peneliti Prodi Keperawatan Blora Politeknik Kesehatan Kemenkes Semarang, sehingga kegiatan penelitian tentang "Perbedaan Mobilisasi Dini 6 Jam dan 8 Jam Terhadap Peristaltik Usus Pada Pasien Post Operasi Dengan anastesi Umum di RS. dr. R. Soeprapto Cepu." dapat terselesaikan.

\section{Pustaka}

1. Abrori, (2005). Operating Room. Instalasi Bedah Central RS dr Sardjito Yogyakarta. Tidak dipublikasikan : Yogyakarta.

2. Alimul. (2006). Pengantar Kebutuhan Dasar Manusia-Aplikasi Konsep dan Proses Keperawatan. Buku I. Jakarata : Salemba Medika.

3. Arikunto, S. (2006). Metodologi Penelitian Suatu Pendekatan Praktek. Jakarta : Rineka Cipta.

4. Asrob.

(2009).

http//robbybee.wordpress.com/ 2009/02/25/Keperawatan Pre-Operatif/

5. Barbara Koizier. (1997). Fundamental of Nursing. Philadelphia Addison Wesly Publising Divission.

6. Carpenito, L. J. (2001). Diagnosa Keperawatan. Alih Bahasa Yasmin Asih. Edisi VIII. Jakarta : EGC.

7. Garrison, S. J. (2007). Manajemen Perioperatif- Penatalaksanaan Pasien Bedah dibangsal. Jakarta : EGC. 
8. Narko \& Arifah. (2008). File ://G:literature\%20skripsi\%203.htm.

9. Notoatmojo, S. (2010). Metodologi Penelitian Kesehatan. Jakarta : Rineka Cipta.

10. Nursalam. (2009). Konsep dan Penerapan Metodologi Penelitian Ilmu Keperawatan. Jakarta : Salemba Medika.

11. Potter \& Perry. (2009). Fundamental Keperawatan. Edisi 4. Volume I. Jakarta : EGC.

12. Rodhianto. (2007). Keperawatan Perioperatif. Bagian Keperawatan Medikal Bedah dan Keperawatan Kritis. Program Studi Ilmu Keperawatan : Universitas Jember.

13. Siregar. C. Trisa. (2004). Artikel-Kebutuhan Dasar Manusia-Eliminasi BAB. PSIK. FK. USU : Sumatera Utara.

14. Smeltzer \& Bare. (2002). Buku Ajar Keperawatan Medikal Bedah. Edisi 8. Volume I. Jakarta : EGC.

15. Sopiyudin Dahlan. (2004). Statistik untuk Kedokteran dan Kesehatan. Cetakan 1. Jakarta : Arkans. 